J. CHEN, X. GONG, J. LI, Y. LI, J. MA, C. HOU, G. ZHAO, W. YUAN*, B. ZHAO* (SHANGHAI NORMAL UNIVERSITY AND CHENGDU INSTITUTE OF ORGANIC CHEMISTRY, P. R. OF

CHINA)

Carbonyl Catalysis Enables a Biomimetic Asymmetric Mannich Reaction

Science 2018, 360, 1438-1442.

\section{Carbonyl-Catalyzed Biomimetic Asymmetric Mannich Reaction}

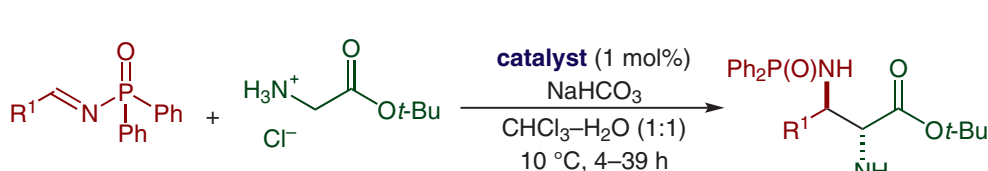

$$
\begin{aligned}
& \mathrm{R}=\mathrm{Ar}, \mathrm{Het} A r
\end{aligned}
$$<smiles>CCCOC(=O)C(N)C(Nc1ccccc1)c1cc(Cl)cc(Cl)c1</smiles><smiles>CCOC(=O)C(N)C(Nc1ccccc1)c1cc2cccc3ccc4cccc1c4c32</smiles>

Gategory

Organo- and Biocatalysis

\section{Key words}

carbonyl catalysis

Mannich reaction

pyridoxal

$\alpha, \beta$-diamino acid esters<smiles>CCOC(=O)[C@H](N)C(NOc1ccccc1)c1csc2ccccc12</smiles>

$67 \%$ yield

$\mathrm{dr}>20: 1$ er $=99: 1$

Proposed reaction mechanism:

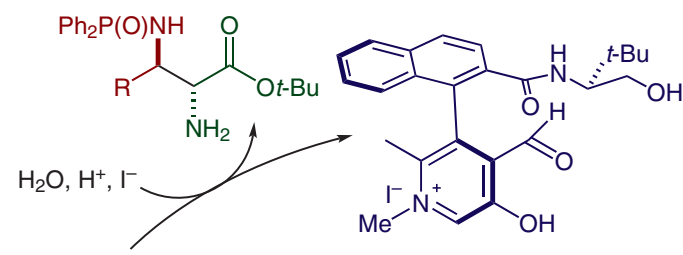

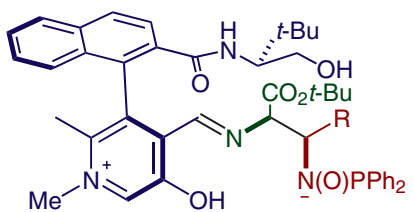

$\mathrm{PPh}_{2}$
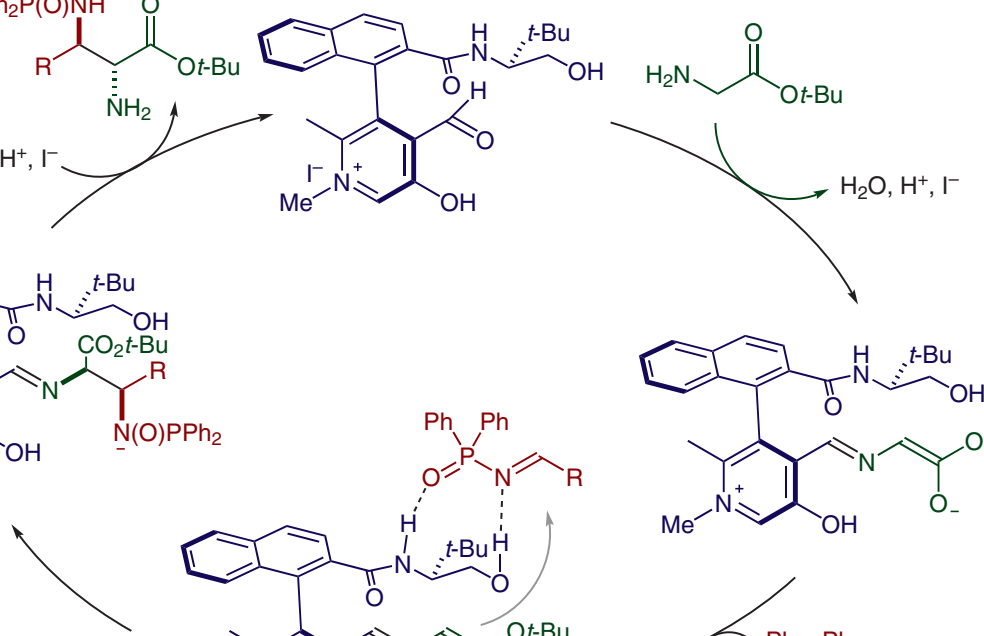

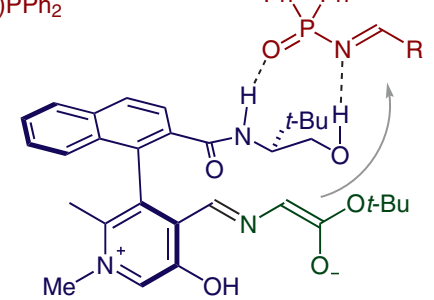<smiles>CCCCOC(O)=CN=Cc1c(O)c[n+](C)c(C)c1-c1c(C(=O)NC(C)(C)C)ccc2ccccc12</smiles><smiles>CCP(=O)(CC)P(=O)(/N=C/P)c1ccccc1</smiles>

Significance: The Zhao group reports the activation of primary amines by carbonyls. Using an $\mathrm{N}$-quaternized pyridoxal catalyst for the direct asymmetric Mannich reaction of glycinate with aryl $N$-diphenylphosphinyl imines, $\alpha, \beta$-diamino acid esters were obtained in good yields and excellent stereoselectivities.

SYNFACTS Contributors: Benjamin List, Oleg Grossmann Synfacts 2018, 14(09), 0975 Published online: 20.08.2018 Dol: 10.1055/s-0037-1610602; Reg-No.: B07118SF
Comment: Based on their recently developed chiral pyridoxal and pyridoxamine catalysts for transamination reactions (J. Am. Chem. Soc. 2016, $138,10730)$, the authors developed a catalyst that activates primary amines through carbonyl catalysis. In contrast to other $\alpha$-functionalizations of primary amines, this fascinating catalysis strategy does not require protecting-group manipulation. 